\title{
Penerapan Metode Pembelajaran Kooperatif Group Investigation Dalam Meningkatkan Kompetensi Mata Pelajaran Pemeliharaan Mesin Kendaraan Di Smk Negeri 3 Kota Jambi
}

\author{
Arman \\ SMK Negeri 3 Kota Jambi \\ Email: armansandiman@yahoo.com)
}

\begin{abstract}
ABSTRAK
Tujuan penelitian ini adalah untuk meningkatkan: (1) Keaktifan siswa secara keseluruhan siswa Kelas XI TKRO 1 SMK Negeri 3 Kota Jambi tahun pelajaran 2020/2021. (2) Hasil belajar siswa Kelas XI TKRO 1 SMK Negeri 3 Kota Jambi. Metodologi penelitian ini adalah penelitian tindakan kelas. Subjek penelitian adalah siswa Kelas XI TKRO 1 SMK Negeri 3 Kota Jambi tahun pelajaran 2020/2021, sejumlah 32 siswa. Teknik pengumpulan data dalam penelitian ini dilakukan melalui kegiatan berupa: (a) observasi keaktifan siswa selama kegiatan pembelajaran berlangsung; (b) wawancara kepada siswa; (c) ulangan harian. Prosedur pelaksanaan tindakan meliputi: (a) perencanaan tindakan; (b) pelaksanaan tindakan; (c) observasi; (d) analisis dan refleksi. Hasil penelitian mengalami peningkatan apabila dibandingkan dengan sebelum penerapan metode GI, yaitu pada aspek semangat dalam KBM pada siklus I yaitu indikator $\mathrm{BS}=5 \% ; \mathrm{B}=70 \% ; \mathrm{C}=22,5 \% ; \mathrm{K}=2,5 \%$ dan pada siklus II indikator $\mathrm{BS}=17,5 \% ; \mathrm{B}=67,5 \% ; \mathrm{C}=15 \%$. Pada pengukuran aspek kerjasama antar siswa mengalami peningkatan yaitu pada siklus $\mathrm{I}$ indikator $\mathrm{B}=22,5 \% ; \mathrm{C}=70 \% ; \mathrm{K}=7,5 \%$ dan pada siklus II indikator $\mathrm{BS}=2,5 \% ; \mathrm{B}=32,5 \% ; \mathrm{C}=60 \% ; \mathrm{K}=5 \%$. Pengukuran aspek mengeluarkan pendapat untuk memecahkan masalah mengalami peningkatan yaitu pada siklus I indikator $\mathrm{B}=20 \% ; \mathrm{C}=47,5 \% ; \mathrm{K}=32,5 \%$ dan pada siklus II indikator $\mathrm{BS}=7,5 \% ; \mathrm{B}=22,5 \% ; \mathrm{C}=57,5 \%$; $\mathrm{K}=12,5 \%$. Pengukuran aspek memberikan pertanyaan juga mengalami peningkatan yaitu pada siklus I indikator $\mathrm{BS}=2,5 \% ; \mathrm{B}=5 \% ; \mathrm{C}=67,5 \% ; \mathrm{K}=15 \%$ dan pada siklus II indikator $\mathrm{BS}=7,5 \% ; \mathrm{B}=22,5 \% ; \mathrm{C}=57,5 \% ; \mathrm{K}=12,5 \%$. Rata-rata ulangan harian siswa siklus II juga mengalami peningkatan sebesar 1,05 (siklus $\mathrm{I}=6,31$; siklus $\mathrm{II}=7,36$ ). Sehingga dapat disimpulkan bahwa metode pembelajaran kooperatif Group Investigation dapat meningkatkan keaktifan siswa dan hasil belajar siswa.
\end{abstract}

Kata Kunci: Group Investigation, Pemeliharaan Mesin Kendaraan

\section{PENDAHULUAN}

Sekolah sebagai suatu institusi atau lembaga pendidikan idealnya harus mampu melakukan proses edukasi, sosialisasi, dan transformasi. Dengan kata lain, sekolah yang bermutu adalah sekolah yang mampu berperan sebagai proses edukasi (proses pendidikan yang menekankan pada kegiatan mendidik dan mengajar), proses sosialisasi (proses bermasyarakat terutama bagi anak didik), dan wadah proses transformasi (proses perubahan tingkah laku ke arah yang lebih baik/ lebih maju). Masalah proses belajar mengajar pada umumnya terjadi di kelas, kelas dalam hal ini dapat berarti segala kegiatan yang dilakukan guru dan anak didiknya di suatu ruangan dalam melaksanakan KBM. Kelas dalam arti luas mencakup interaksi guru dan siswa, teknik dan strategi belajar mengajar, dan implementasi kurikulum serta evaluasinya. (Kasihani Kasbolah E.S, 2001:1) 
Menurut hasil pengamatan yang dilakukan peneliti melalui observasi kelas dan wawancara dengan guru mata pelajaran semester genap di SMK Negeri 3 Kota Jambi tahun pelajaran 2020/2021 menunjukkan bahwa pencapaian kompetensi mata pelajaran PMKR siswa kurang optimal. Asumsi dasar yang menyebabkan pencapaian kompetensi mata pelajaran PMKR siswa kurang optimal adalah pemilihan metode pembelajaran dan kurangnya peran serta (keaktifan) siswa dalam KBM. Metode mengajar guru masih secara konvensional. Proses belajar mengajar PMKR masih terfokus pada guru dan kurang terfokus pada siswa. Hal ini mengakibatkan kegiatan belajar mengajar (KBM) lebih menekankan pada pengajaran daripada pembelajaran. Metode pembelajaran yang digunakan lebih didominasi oleh siswa-siswa tertentu saja. Peran serta siswa belum menyeluruh sehingga menyebabkan diskriminasi dalam kegiatan pembelajaran. Siswa yang aktif dalam KBM cenderung lebih aktif dalam bertanya dan menggali informasi dari guru maupun sumber belajar yang lain sehingga cenderung memiliki pencapaian kompetensi belajar yang lebih tinggi. Siswa yang kurang aktif cenderung pasif dalam KBM, mereka hanya menerima pengetahuan yang datang padanya sehingga memiliki pencapaian kompetensi yang lebih rendah.

Berdasarkan pertimbangan tersebut, maka perlu dikembangkan suatu metode pembelajaran yang mampu melibatkan peran serta siswa secara menyeluruh sehingga kegiatan belajar mengajar tidak hanya didominasi oleh siswa-siswa tertentu saja. Selain itu, melalui pemilihan metode pembelajaran tersebut diharapkan sumber informasi yang diterima siswa tidak hanya dari guru melainkan juga dapat meningkatkan peran serta dan keaktifan siswa dalam mempelajari dan menelaah ilmu yang ada terutama mata pelajaran PMKR.

Salah satu metode pembelajaran yang melibatkan peran serta siswa adalah metode pembelajaran kooperatif. Dalam metode pembelajaran kooperatif lebih menitikberatkan pada proses belajar pada kelompok dan bukan mengerjakan sesuatu bersama kelompok. Proses belajar dalam kelompok akan membantu siswa menemukan dan membangun sendiri pemahaman mereka tentang materi pelajaran yang tidak dapat ditemui pada metode konvensional.

Peneliti dalam hal ini mencoba mengkaji penerapan metode pembelajaran kooperatif Group Investigation (GI) dalam proses pembalajaran. Group Investigation adalah metode pembelajaran yang melibatkan siswa sejak perencanaan, baik dalam menentukan topik maupun cara untuk mempelajarinya melalui investigasi. Metode pembelajaran ini menuntut para siswa untuk memiliki kemampuan yang baik dalam berkomunikasi maupun dalam ketrampilan proses kelompok (group process skills). Para siswa memilih topik yang ingin dipelajari, mengikuti investigasi mendalam terhadap berbagai subtopik yang telah dipilih, kemudian menyiapkan dan menyajikan dalam suatu laporan di depan kelas secara keseluruhan.

Pusat dari investigasi kelompok adalah perencanaan kooperatif murid dalam melakukan penyelidikan terhadap topik yang telah diidentifikasikan. Anggota kelompok mengambil peran dalam menentukan apa yang akan mereka selidiki, siapa yang akan mengerjakan dan bagaimana mereka mempresentasikan hasil secara keseluruhan di depan kelas. Kelompok pada pembelajaran berbasis investigasi kelompok ini merupakan kelompok yang heterogen baik dari jenis kelamin maupun kemampuannya. Setiap kelompok terdiri dari 4-5 orang. Di dalam kelompok tersebut, setiap siswa dalam kelompok mengejakan apa yang telah menjadi 
tugasnya dalam lembar kerja kegiatan secara mandiri yang telah disiapkan dan teman sekelompoknya bertanggungjawab untuk saling memberi kontribusi, saling tukar-menukar dan mengumpulkan ide. Setelah itu anggota kelompok merencanakan apa yang akan dilaporkan dan bagaimana membuat presentasinya. Langkah terakhir dalam kegiatan ini, salah satu anggota kelompok mengkoordinasikan rencana yang akan dipresentasikan di depan kelompok yang lebih besar.

\section{METODE}

Jenis penelitian yang dilaksanakan oleh peneliti adalah Penelitian Tindakan Kelas (Class Room Action Research). Berdasarkan tujuan penelitian, maka jelas bahwa penelitian ini tidak menguji hipotesis secara kuantitatif, akan tetapi lebih bersifat untuk mendiskrPMKRikan data, fakta dan keadaan yang ada. Kegiatan peneliti di lapangan adalah menyusun rencana kegiatan, melaksanakan observasi, mengadakan wawancara dengan subjek penelitian, mengadakan evaluasi dan akhirnya melaporkan hasil penelitian.

Pendekatan yang digunakan adalah model Kemmis dan Mc Taggar dalam Kasihani Kasbolah (2001: 63-65) yang berupa model spiral. Dalam perencanaan, Kemmis menggunakan sistem spiral refleksi diri yang dimulai dengan rencana, tindakan, pengamatan, refleksi dan perencanaan kembali sebagai dasar untuk suatu ancang-ancang masalah. Dalam penelitian ini peneliti menerapkan siklus I dan siklus II untuk melakukan perbaikan pembelajaran dan meggunakan kelas paralel dalam perbaikan tindakan.

\section{Teknik Pengumpulan Data}

Untuk memecahkan masalah dalam penelitian diperlukan data yang relevan dengan permasalahannya, sedangkan untuk mendapatkan data tersebut perlu digunakan teknik pengumpulan data sehingga dapat diperoleh data yang benar-benar valid dan dapat dipercaya. Teknik pengumpulan data yang digunakan dalam penelitian ini adalah:

\section{Metode Observasi}

Teknik ini dilakukan dengan cara mengamati terhadap objek penelitian dan mencatat fenomena yang diselidiki. Menurut Spradley dalam H. B Sutopo (2002:65) pelaksanaan teknik observasi dapat dibagi menjadi:

\section{Observasi Tak Berperan}

Dalam observasi ini, peneliti sama sekali kahadirannya dalam melakukan observasi tidak diketahui oleh subjek yang diamati.

\section{Observasi Berperan}

Pada observasi yang dilakukan dengan mendatangi peristiwanya, kehadiran peneliti di lokasi sudah menunjukkan peran yang paling pasif, sebab kehadirannya sebagai orang asing diketahui oleh yang diamati, dan bagaimanapun hal itu membawa pengaruh pada yang diamati. Observasi dalam penelitian ini adalah observasi berperan pasif dan menggunakan jenis observasi terstruktur, karena peneliti hanya berperan sebagai pengamat pelaksanaan 
metode pembelajaran kooperatif Group Investigation (GI) yang berpedoman pada lembar observasi yang telah disusun peneliti.

Teknik observasi digunakan untuk mengumpulkan data mengenai keaktifan siswa dalam proses pembelajaran dan kegiatan belajar mengajar yang meliputi metode dan strategi kegiatan belajar mengajar. Observasi merupakan proses perekaman dengan mengamati semua peristiwa dan kegiatan yang terjadi selama penelian tindakan kelas berlangsung.

\section{Prosedur Pelaksanaan Tindakan}

\section{Perencanaan Tindakan}

Kegiatan yang dilakukan dalam tahap ini adalah:

1. Menyiapkan perangkat pembelajaran yang meliputi: silabus mata pelajaran PMKR dan skenario pembelajaran dengan menggunakan metode pembelajaran kooperatif Group Investigation dimana siswa dapat mendengar, melihat, mendiskusikan dan menerapkan topik pembelajaran.

2. Menyusun instrumen penelitian. Instrumen yang digunakan dalam penelitian ini adalah lembar observasi. Lembar observasi tersebut digunakan untuk mengetahui kondisi belajar siswa dengan adanya penerapan metode pembelajaran Group Investigation dan mengetahui peran serta atau keaktifan siswa selama proses pembelajaran berlangsung baik pada siklus I maupun siklus II.

3. Menyiapkan sumber bahan yang sesuai dengan standar kompetensi dan kompetensi dasar. Materi pokok yang digunakan dalam penerapan metode pembelajarn Group Investigation (GI) untuk siklus I dan II perawatan karburator.

4. Menyiapkan media pembelajaran yang diperlukan sesuai dengan skenario pembelajaran.

5. Mendesain alat evaluasi berupa soal tes untuk mengetahui tingkat hasil belajar siswa setelah adanya pelaksanaan metode Group Investigation (GI).

\section{Pelaksanaan Tindakan}

Pada tahap pelaksanaan tidakan aspek collaborative participatori antara tim peneliti sangat penting dan menonjol. Hubungan kolaborasi tersebut harus tercipta dalam suasana demokratis agar implementasi rencana tindakan dapat berjalan dalam suasana efektif dan efisien. Guru dan peneliti berkolaborasi untuk mengetahui apakah setelah tindakan dilakukan terjadi perubahan atau peningkatan sehingga diperlukan suatu gambaran tentang keadaan awal. Dari gambaran tersebut dapat ditentukan apa yang harus diubah, diperbaiki atau ditingkatkan. Dengan diketahuinya keadaan awal, maka perubahan dan peningkatan dapat diikuti dari waktu ke waktu selama tindakan dilaksanakan (Kasihani Kasbolah, 2001: 49).

Adapun langkah-langkah pelaksanaan tindakan metode pembelajaran kooperatif Group Investigation (GI) pada siklus I dan II secara rinci sebagai berikut:

1. Membagi siswa menjadi delapan kelompok dan setiap kelompok beranggotakan lima orang.

2. Membagi materi menjadi delapan topik, kemudian materi tersebut diberikan kepada masing-masing kelompok untuk diidentifikasikan.

3. Setiap kelompok merencanakan tugas belajar dan menjalankan investigasi kelompok. 
4. Tiap-tiap kelompok menyiapkan laporan akhir dengan menunjuk salah satu anggota kelompok untuk mempresentasikan tentang laporan hasil penyelidikannya yang kemudian setiap anggota mendengarkan.

5. Setiap kelompok mempresentasikan laporan hasil akhirnya di depan kelas, sedangkan kelompok lain dapat aktif mengevaluasi laporan tiap-tiap kelompok dengan berbagai tanya jawab, kritik maupun saran.

\section{Observasi}

Bersamaan dengan dilaksanakannya tindakan peneliti melakukan observasi terhadap pelaksanaan dan hasil tindakan dari penerapan metode pembelajaran Group Investigation. Tujuan dari observasi tersebut adalah untuk mengetahui seberapa jauh pelaksanaan tindakan yang sedang berlangsung dapat diharapkan akan mengahasilkan perubahan yang diinginkan.

Peneliti bertugas sebagai pengamat pelaksanaan Kegiatan Belajar Mengajar (KBM). Fokus pengamatan ditekankan pada implementasi pembelajaran kooperatif Group Investigation (GI) terhadap kualitas pembelajaran secara menyeluruh yang meliputi: peran serta siswa dalam Kegiatan Belajar Mengajar dan pencapaian hasil belajar siswa.

Observasi yang dilakukan pada setiap siklus adalah sebagai berikut:

1. Keaktifan siswa dalam proses pembelajaran

2. Kemampuan mengerjakan tugas

3. Tanggapan siswa terhadap strategi pembelajaran dengan menggunakan metode Group Investigation

4. Suasana kegiatan belajar mengajar

\section{Analisis dan Refleksi}

Kegiatan refleksi ini mencakup kegiatan analisis, interpretasi dan evaluasi atas informasi yang diperoleh dari kegiatan observasi. Data yang telah terkumpul dalam kegiatan observasi harus secepatnya dianalisis dan diinterpretasi (diberi makna) sehingga dapat segera diketahui apakah tindakan yang dilakukan telah mencapai tujuan. Interpretasi (pemaknaan) hasil observasi ini menjadi dasar untuk melakukan evaluasi sehingga dapat disusun langkahlangkah berikutnya dalam pelaksanaan tindakan.

Refleksi dalam penelitian ini adalah upaya untuk mengkaji apa yang telah terjadi dan apa yang telah dihasilkan pada proses tindakan dihubungkan dengan penyelesaian permasalahan yang ditargetkan pada siklus tersebut. Pada tahap ini hasil observasi dikumpulkan dan dianalisis oleh peneliti, untuk kemudian dilakukan refleksi untuk melihat kekurangan atau kelemahan yang telah terjadi. Pada tahap ini pula dilakukan diskusi oleh siswa mengenai pelaksanaan pembelajaran yang telah terjadi. Hasil refleksi ini akan digunakan dalam perencanaan siklus berikutnya.

Berdasarkan pelaksanaan tahap observasi dan evaluasi sebelumnya, data yang diperoleh selanjutnya menjadi bahan refleksi bagi peneliti untuk perbaikan metode pembelajaran materi pokok berikutnya (pada siklus II). Salah satu aspek penting dari kegiatan refleksi adalah melakukan evaluasi terhadap keberhasilan dan pencapaian tujuan tindakan

Setelah kegiatan penelitian ini diharapkan ada tindak lanjut dari guru PMKR berupa: 1). Peningkatan profesionalisme jabatan guru terutama untuk memperbaiki proses pembelajaran 
yang berkelanjutan. 2). Mampu mengembangkan strategi pembelajaran agar kompetensi pembelajaran dapat tercapai dengan baik.

Secara skematis prosedur penelitian dapat digambarkan sebagai berikut:

\section{Siklus I}

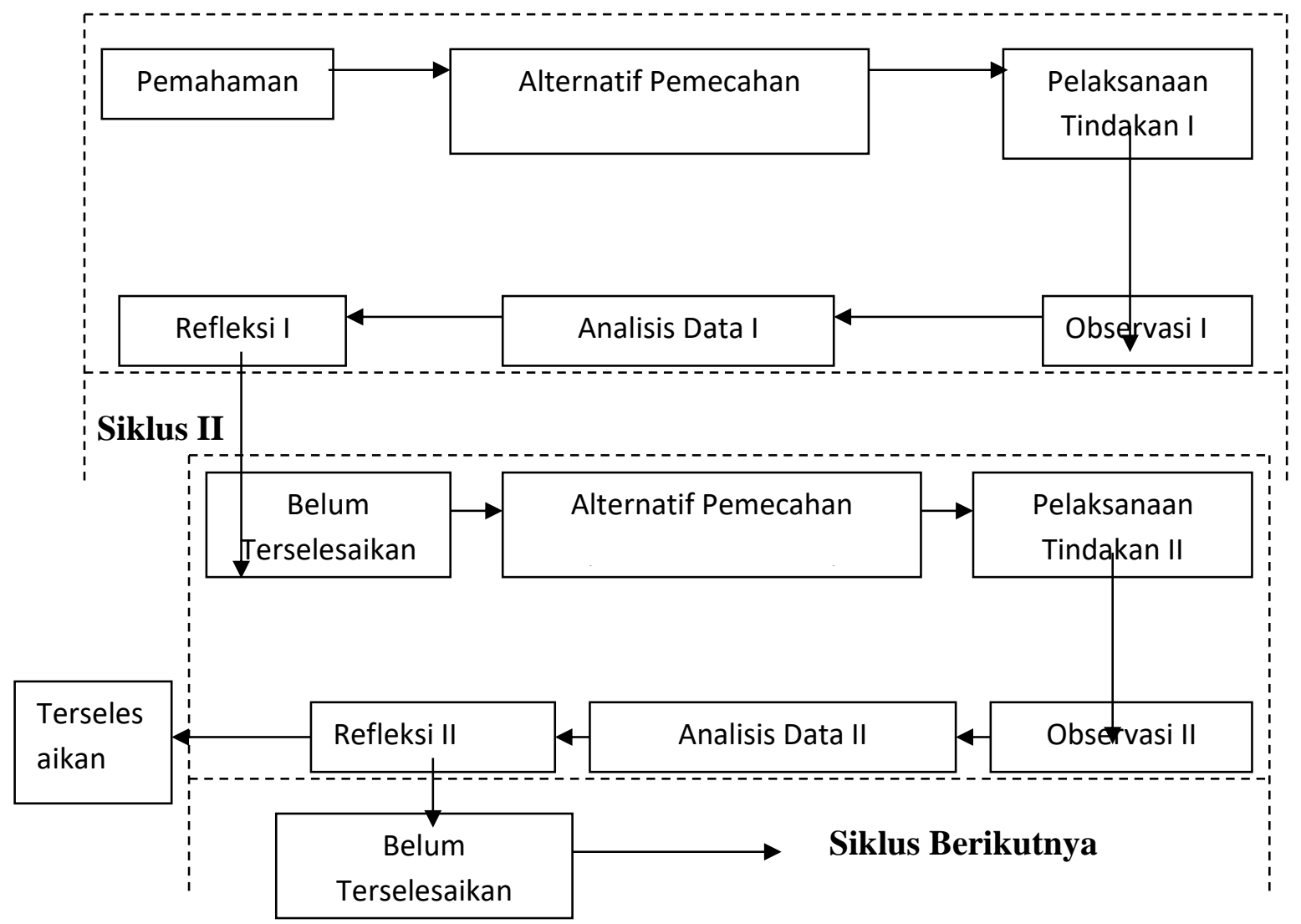

TEMUAN PENELITIAN

\section{Siklus I}

\section{Perencanan Tindakan}

Langkah-langkah atau tindakan yang akan dilakukan, direncanakan secara rinci oleh guru dan peneliti sehingga benar-benar dapat dijadikan pegangan dalam melaksanakan tindakan. Peneliti menyusun lembar observasi yang akan digunakan untuk mengetahui keaktifan siswa selama mengikuti proses pembelajaran dengan menggunakan metode pembelajan kooperatif Group Investigation (GI) dan untuk mengetahui tingkat penerimaan siswa terhadap materi pelajaran yang diberikan selama kegiatan belajar mengajar. Sebagai alat evaluasi guru membuat soal ulangan berbentuk pilihan ganda untuk mengetahui tingkat hasil belajar siswa setelah adanya penerapan metode Group Investigation (GI).

\section{Pelaksanaan Tindakan}


Pada pelaksanaan tindakan dilakukan suatu tindakan yang dapat menghasilkan adanya peningkatan dalam proses pembelajaran yang berupa pembelajaran menjadi lebih efektif, siswa menjadi aktif dalam mengikuti kegiatan belajar mengajar dan hasil belajar siswa dapat meningkat. Jenis tindakan beserta kelengkapannya yang telah direncanakan dengan baik oleh guru dan peneliti, maka guru tinggal melaksanakan skenario tindakan yang telah ditetapkan. Untuk mengetahui tindakan yang dilakukan oleh guru sesuai dengan rencana, maka selama guru melaksanakan tindakan peneliti melakukan pemantauan terhadap proses pembelajaran di kelas.

Pada awal pelaksanaan tindakan diberikan suatu pengarahan tentang metode pembelajaran kooperatif Group Investigation (GI) kepada siswa, hal ini bertujuan agar dalam pelaksanaan metode tersebut akan dapat berjalan dengan lancar. Pengarahan yang diberikan berupa pengertian dari metode pembelajaran kooperatif Group Investigation (GI). Pengarahan tersebut berupa tahap-tahap pelaksanaan pada pembelajaran kooperatif Group Investigation (GI), yang meliputi mengidentifikasi topik, merencanakan tugas belajar, melaksanakan investigasi kelompok, menyusun laporan akhir dan melaksanakan presentasi di depan kelas. Dengan adanya pengarahan tersebut maka siswa akan mendapatkan gambaran yang jelas tentang metode Group Investigation (GI) tersebut, sehingga siswa dapat melaksanakan dengan baik kegiatan-kegiatan yang akan dilakukan pada tiap tahapan. Selain itu guru juga memberikan penjelasan tentang aspek-aspek yang dinilai selama metode pembelajaran kooperatif Group Investigation (GI) dilaksanakan, yaitu kontribusi siswa terhadap kelompoknya mulai dari mengidentifikasi topik, merencanakan tugas belajar, investigasi kelompok dan menyiapkan laporan akhir. Aspek lain yang dinilai adalah keaktifan siswa selama presentasi berlangsung. Secara rinci tahap-tahap pelaksanaan metode pembelajaran kooperatif Group Investigation (GI) adalah sebagai berikut:

(1) Mengidentifikasikan topik dan pembentukan kelompok.

Pembagian kelompok dilakukan secara heterogen yang didasarkan pada nilai hasil ulangan harian pokok bahasan sebelumnya yaitu Kegiatan Pokok PMKR Dalam Kehidupan Sehari-hari. Kelompok untuk penerapan metode pembelajaran Group Investigation (GI) terbagi menjadi delapan kelompok dan setiap kelompok beranggotakan lima orang.

Materi / topik yang didiskusikan antara lain:
Kelompok I
: Tanki bahan bakar
Kelompok II
: Pipa bahan bakar
Kelompok III
: Saringan bahan bakar
Kelompok IV
: Pompa bahan bakar
Kelompok V
: Karburator
Kelompok VI
: Intake manipold
Kelompok VII
: Kerusakan system Bahan bakar
Kelompok XIII
: Pemeliharaan system bahan bakar

(2) Merencanakan tugas belajar

Pada tahap ini anggota kelompok menentukan sub topik yang akan diinvestigasi dan masing-masing anggota kelompok mengumpulkan sumber-sumber untuk memecahkan masalah yang tengah diidentifikasi. Setiap siswa dituntut untuk 
menyumbangkan konstribusinya terhadap investigasi kelompoknya masing-masing kemudian setiap kelompok memberikan konstribusi terhadap penelitian untuk seluruh kelas.

(3) Menjalankan investigasi

Siswa secara individu atau berpasangan mengumpulkan informasi, menganalisa dan mengevaluasi serta menarik kesimpulan. Setiap anggota kelompok memberikan konstribusi satu dari bagian penting yang lain untuk mendiskusikan pekerjaannya dengan saling mengadakan tukar menukar informasi dan mengumpulkan ide-ide tersebut untuk menjadi suatu kesimpulan.

(4) Menyiapkan laporan akhir

Tahap ini merupakan tingkat pengorganisasian dan mengintegrasikan semua bagian menjadi keseluruhan dan merencanakan sebuah presentasi di depan kelas. Setiap kelompok telah menunjuk salah satu anggota untuk mempresentasikan laporan hasil penyelidikannya kemudian setiap anggota mendengarkan. Peran guru disini sebagai penasehat dan membantu memastikan setiap anggota kelompok ikut andil didalamnya.

(5) Mempresentasikan laporan hasil akhir

Setiap kelompok telah siap memberikan hasil akhir di depan kelas dalam bentuk presentasi secara keseluruhan. Diharapkan dari penyajian presentasi kelompok lain dapat aktif mengevaluasi kejelasan dari laporan setiap kelompok dengan melakukan tanya jawab.

(6) Mengevaluasi

Pada tahap ini siswa memberikan tanggapan dari masing-masing topik yang disajikan tiap kelompok. Sedangkan guru dan siswa yang lain berkolaborasi mengevaluasi proses belajar sehingga semua siswa diharapkan menguasai semua sub topik yang disajikan.

Pelaksanaan metode pembelajaran kooperatif Group Investigation (GI) yang melalui beberapa tahapan dapat menuntut siswa harus berperan aktif dalam setiap tahapannya. Pada pelaksanaan tindakan ini akan diketahui peran serta siswa dalam kegiatan pembelajaran. Setelah selesai dilaksanakan metode Group Investigation pada siklus I guru memberikan tugas pada siswa untuk dikerjakan di rumah, hal ini bertujuan agar siswa dapat lebih memahami materi pelajaran yang telah dilaksanakan. Kegiatan pelaksanaan siklus I diakhiri dengan ulangan harian. Ulangan harian ini diadakan dengan tujuan untuk mengetahui tingkat hasil belajar siswa setelah adanya penerapan metode pembelajaran kooperatif Group Investigation (GI).

\section{Observasi dan Evaluasi}

Pada tahap ini peneliti melakukan pengamatan dengan berpedoman pada lembar observasi yang telah disusun. Observasi tersebut dilakukan untuk mengetahui keaktifan siswa dalam pelaksanaan kegiatan belajar mengajar dan untuk mengetahui kemampuan siswa menerima materi pelajaran dengan adanya metode pembelajaran kooperatif Group Investigation (GI). Observasi ini dilakukan bersamaan dengan kegiatan pelaksanaan tindakan. Fokus pengamatan ditekankan pada implementasi pembelajaran kooperatif Group Investigation (GI) 
terhadap kualitas pembelajaran secara menyeluruh yang meliputi: keaktifan siswa dalam proses pembelajaran, tanggapan siswa terhadap metode pembelajaran yang telah digunakan yaitu metode pembelajaran kooperatif Group Investigation (GI), suasana kegiatan belajar mengajar dan pencapaian hasil belajar siswa.

Pada saat observasi berlangsung kegiatan guru adalah sebagai pemantau pelaksanaan metode pembelajaran kooperatif Group Investigation (GI). Guru memberi bantuan atau penjelasan pada siswa atau kelompok yang kurang paham terhadap tugas yang harus mereka kerjakan yang berkaitan dengan kegiatan pokok PMKR. Selain itu guru juga melakukan penilaian terhadap siswa yang aktif dalam presentasi di depan kelas. Kegiatan siswa pada saat presentasi berlangsung, siswa melaksanakan diskusi dalam kelompok mereka masing-masing sesuai dengan topik yang telah ditentukan. Pada siklus I ini materi pelajaran yang digunakan adalah Kegiatan Pokok PMKR.

Selama kegiatan pembelajaran kooperatif Group Investigation (GI) berlangsung siswa memperhatikan penjelasan yang diberikan oleh guru, baik penjelasan tentang pelaksanaan metode pembelajaran kooperatif Group Investigation (GI) maupun penjelasan tentang materi yang akan dipergunakan yaitu Kegiatan Pokok PMKR. Proses pembelajaran pada materi Kegiatan Pokok PMKR berjalan dengan lancar. Siswa melaksanakan diskusi dalam kelompoknya masing-masing dengan baik, sebagian besar siswa sudah dapat memberikan kontribusi bagi kelompoknya masing-masing terhadap materi yang mereka diskusikan. Kegiatan diskusi dalam kelompok didominasi dengan saling bertukar pendapat antar anggota kelompok, mereka bekerja sama dalam menyusun laporan akhir tentang materi pelajaran yang mereka investigasi. Keaktifan siswa mengalami peningkatan, terbukti dengan siswa yang semula tidak berani mengeluarkan pendapat menjadi berani berpendapat, misalnya pada saat pelaksanaan presentasi di depan kelas, siswa anggota kelompok lain ikut mengevaluasi dan bertanya tentang penyajian materi yang belum dipahami. Kegiatan observasi ini diperlukan untuk mengetahui tindakan yang telah dilakukan untuk dapat dievaluasi keefektifannya.

\section{Analisis dan Refleksi}

Pada tahap ini hasil observasi akan dikumpulkan dan dianalisis kemudian dilakukan refleksi untuk kegiatan yang telah dilakukan dapat meningkatkan keaktifan siswa dan dapat meningkatkan hasil belajar siswa pada meta pelajaran PMKR. Hasil analisis data yang dilakukan pada tahap ini akan dipergunakan sebagai acuan untuk merencanakan siklus berikutnya.

\section{Siklus II}

\section{Perencanaan Tindakan 2}

Proses kegiatan belajar mengajar masih berpusat pada aktivitas siswa dan guru seperti pada pelaksanaan siklus I. seperti dengan siklus I pada tahap ini guru mempersiapkan media yang digunakan dalam kegiatan belajar mengajar dan menyusun silabus mata pelajaran PMKR. Pada siklus II materi yang diberikan adalah bahan bakar bensin. 
Seperti pada siklus I, guru mempersiapkan media pembelajaran dan bersama-sama peneliti menyusun tindakan-tindakan yang akan dilakukan. Sebagai alat evaluasi guru membuat soal tes ulangan untuk mengetahui tingkat hasil belajar siswa.

\section{Pelaksanaan Tindakan 2}

Pada sikluis II, kegiatannya sama dengan siklus I yang didahului dengan memberikan pengarahan tentang pelaksanaan kegiatan pembelajaran dengan menggunakan metode pembelajaran kooperatif Group Investigation (GI) kepada siswa. Tahap pelaksanaan tindakan pembelajaran pada siklus II ini sama seperti pada siklus I, meliputi:

(1) Mengidentifikasikan topik dan menentukan kelompok

Pembagian kelompok didasarkan pada nilai hasil ulangan harian pada saat siklus I.

Kelas GI terbagi menjadi 8 kelompok dan setiap kelompok beranggotakan 5 orang.

Materi pokok dibagi menjadi 8 bagian dan dibagikan secara acak kepada tiap-tiap kelompok. Pembagian kelompok dan materi adalah sebagai berikut:
Kelompok I
Kelompok II
: angka oktan
Kelompok III
: bahan bakar premium
Kelompok IV
: bahan bakar pertalite
Kelompok V
: bahan bakar pertamax
Kelompok VI
: bahan bakar pertamax plus
Kelompok VII
: pertamax turbo
Kelompok VIII
: solar

: Gangguan pada sistem bahan bakar

(2) Merencanakan tugas belajar

Setiap anggota kelompok mengumpulkan berbagai sumber untuk memecahkan masalah yang telah diinvestigasi. Setiap siswa saling memberikan kontribusinya terhadap investigasi kelompok kecil.

(3) Menjalankan investigasi

Siswa secara individual atau berpasangan mengumpulkan informasi, menganalisa dan mengevaluasi serta menarik kesimpulan. Setiap anggota kelompok memberikan kontribusi, saling menukar informasi dan mengumpulkan ide-ide menjadi suatu kesimpulan.

(4) Menyiapkan laporan akhir

Tahap ini merupakan tingkat pengorganisasian dan mengintegrasikan semua bagian menjadi keseluruhan dan merencanakan sebuah presentasi di depan kelas. Setiap kelompok telah menunjuk salah satu dari anggotanya untuk mempresentasikan tentang laporan hasil penyelidikan kelompoknya. Kemudian setiap anggotanya mendengarkan.

(5) Mempresentasikan laporan hasil akhir

Setiap kelompok telah siap memberikan hasil akhir di depan kelas dalam bentuk presentasi. Diharapkan dari penyajian presentasi, kelompok lain dapat aktif mengevaluasi kejelassan dari laporan setiap kelompok dengan melakukan tanya jawab.

(6) Mengevaluasi

Pada tahap ini setiap siswa memberikan tanggapan dari masing-masing materi yang disajikan tiap kelompok. Sedangkan guru dan siswa yang lain berkolaborasi 
mengevaluasi proses belajar sehingga semua siswa diharapkan menguasai semua materi yang disajikan.

\section{Observasi}

Pada tahap ini peneliti melakukan pengamatan dengan berpedoman pada lembar observasi yang telah disusun. Observasi tersebut dilakukan untuk mengetahui keaktifan siswa dalam pelaksanaan kegiatan belajar mengajar dan untuk mengetahui kemampuan siswa menerima materi pelajaran dengan adanya metode pembelajaran kooperatif Group Investigation (GI). Observasi ini dilakukan bersamaan dengan kegiatan pelaksanaan tindakan. Fokus pengamatan ditekankan pada implementasi pembelajaran kooperatif Group Investigation (GI) terhadap kualitas pembelajaran secara menyeluruh yang meliputi: keaktifan siswa dalam proses pembelajaran, tanggapan siswa terhadap metode pembelajaran yang telah digunakan yaitu metode pembelajaran kooperatif Group Investigation (GI), suasana kegiatan belajar mengajar dan pencapaian hasil belajar siswa.

\section{Analisis dan Refleksi}

Pada tahap ini hasil observasi akan dikumpulkan dan dianalisis kemudian dilakukan refleksi untuk kegiatan yang telah dilakukan dapat meningkatkan keaktifan siswa dan dapat meningkatkan hasil belajar siswa pada meta pelajaran PMKR. Hasil analisis data yang dilakukan pada tahap ini akan dipergunakan sebagai acuan untuk merencanakan siklus berikutnya.

\section{PEMBAHASAN}

Berdasarkan data yang diperoleh secara CAR (Classroom Action Research) menunjukkan bahwa penerapan metode pembelajaran kooperatif Group Investigation (GI) dapat meningkatkan keaktifan siswa kelas XI TKRO 1 SMK Negeri 3 Kota Jambi. Hal ini dapat dibuktikan dari lembar observasi yang menunjukkan bahwa terdapat perbedaan keaktifan siswa antara yang belum menggunakan metode pembelajaran kooperatif Group Investigation (GI) dan yang telah menggunakan metode pembelajaran kooperatif Group Investigation (GI). Peningkatan ini menunjukkan bahwa proses pembelajaran dengan metode pembelajaran kooperatif Group Investigation (GI) menjadikan KBM menjadi lebih efektif sebab siswa banyak berperan dalam memecahkan suatu permasalahan.

Berdasarkan data pada tabel 1 keaktifan siswa pada aspek "semangat siswa dalam kegiatan belajar mengajar" terlihat adanya peningkatan skor. Sebelum menggunakan metode pembelajaran kooperatif Group Investigation (GI) untuk indikator BS (Baik Sekali) tidak ada skor persentasenya, untuk indikator B (Baik) nilai skor persentasenya 60\%, untuk indikator C (Cukup) nilai skor persentasenya 32,5\% dan untuk indikator K (Kurang) skor persentasenya 7,5\%. Setelah meggunakan metode pembelajaran kooperatif Group Investigation (GI) pada siklus I dan siklus II masing-masing indikator terjadi peningkatan, yaitu untuk indikator BS naik menjadi 5\% pada siklus I dan 17,5\% pada siklus II. Untuk indikator B (Baik) juga terjadi peningkatan yaitu menjadi $70 \%$ pada siklus I dan $67,5 \%$ pada siklus II. Sedangkan indikator $\mathrm{C}$ (Cukup) dan $\mathrm{K}$ (Kurang) mengalami penurunan yaitu indikator $\mathrm{C}$ menjadi 22,5\% pada siklus I dan $15 \%$ pada siklus II, indikator $\mathrm{K}$ menjadi $2,5 \%$ pada siklus I dan tidak ada 
persentase pada siklus II. Penurunan indikator C dan $\mathrm{K}$ pada siklus I dan siklus II menunjukkan bahwa telah terjadi peningkatan keaktifan siswa untuk aspek semangat siswa dalam mengikuti kegiatan belajar mengajar.

Aspek yang kedua dari keaktifan siswa adalah "kerjasama" juga mengalami peningkatan skor. Untuk indikator BS (Baik Sekali) sebelum menggunakan metode pembelajaran kooperatif Group Investigation (GI) tidak ada skor persentasenya, namun setelah menggunakan metode pembelajaran kooperatif Group Investigation (GI) ada peningkatan menjadi 2,5\% pada siklus II. Untuk indikator B sebelum menggunakan metode pembelajaran kooperatif Group Investigation (GI) sebesar 10\% dan setelah diterapkan metode pembelajaran kooperatif Group Investigation (GI) tejadi peningkatan menjadi 22,5\% pada siklus I dan 32,5\% pada siklus II. Sedangkan untuk indikator C (Cukup) juga terjadi peningkatan yaitu sebelum diterapkan metode pembelajaran kooperatif Group Investigation (GI) sebesar $40 \%$ dan setelah diterapkan sebesar 70\% pada siklus I dan $60 \%$ pada siklus II. Untuik indikator $\mathrm{K}$ terjadi penurunan skor persentase, yaitu indikator $\mathrm{K}$ dari $50 \%$ menjadi 7,5\% pada siklus I dan 5\% pada siklus II.

Aspek yang ketiga dari keaktifan siswa adalah "mengeluarkan pendapat untuk memecahkan permasalahan". Pada aspek ini juga terjadi peningkatan skor persentase pada masing-masing indikator. Sebelum menggunakan metode pembelajaran kooperatif Group Investigation (GI) indikator BS (Baik Sekali) 0\%, untuk indikator B (Baik) sebesar 17,5\%, indikator C (Cukup) sebesar 45\% dan indikator K (Kurang) sebesar 37,5\%. Setelah menggunakan metode pembelajaran kooperatif Group Investigation (GI) pada siklus I dan siklus II masing-masing indikator mengalami peningkatan, yaitu untuk indikator BS naik menjadi 2,5\% pada siklus II. Untuk indikator B juga terjadi peningkatan yaitu menjadi $20 \%$ pada siklus I dan $17,5 \%$ pada siklus II. Untuk indikator $\mathrm{C}$ juga mengalami peningkatan yaitu menjadi $67,5 \%$ pada siklus I dan $57,5 \%$ pada siklus II. Sedangkan untuk indikator K (Kurang) mengalami penurunan yaitu menjadi $15 \%$ pada siklus I dan $12,5 \%$ pada siklus II. Penurunan untuk indikator K pada siklus I dan siklus II menunjukkan bahwa telah terjadi peningkatan keaktifan siswa untuk aspek mengeluarkan pendapat untuk memecahkan suatu permasalahan.

Aspek yang keempat dari keaktifan siswa adalah "memberikan pertanyaan (bertanya)" juga mengalami peningkatan skor. Dari data tabel 4 menunjukkan bahwa sebelum menggunakan metode pembelajaran kooperatif Group Investigation (GI) untuk indikator BS tidak ada skor persentasenya, untuk indikator B nilai skor persentasenya $17,5 \%$, indikator C sebesar 47,5\% dan indikator K sebesar 35\%. Setelah menggunakan metode pembelajaran kooperatif Group Investigation (GI) pada siklus I dan siklus II terjadi peningkatan, yaitu untuk indikator BS naik menjadi 2,5\% pada siklus I dan 7,5\% pada siklus II. Untuk indikator B naik menjadi $15 \%$ pada siklus I dan $22,5 \%$ pada siklus II. Untuk indikator C mengalami peningkatan yaitu $67,5 \%$ pada siklus I dan $57,5 \%$ pada siklus II. Sedangkan indikator K mengalami penurunan yaitu sebesar $15 \%$ pada siklus I dan $12,5 \%$ pada siklus II. Penurunan ini menunjukkan bahwa dengan adanya penerapan metode pembelajaran kooperatif Group Investigation (GI) siswa menjadi lebih aktif bertanya.

Tabel 1. Pengukuran Keaktifan Siswa Dalam Kegiatan Belajar Mengajar 


\begin{tabular}{|l|c|c|c|c|c|}
\hline \multirow{2}{*}{ KEADAAN } & \multicolumn{5}{c|}{ PERSENTASE SKOR } \\
\cline { 2 - 6 } & $\mathrm{BS}$ & $\mathrm{B}$ & $\mathrm{C}$ & $\mathrm{K}$ & $\mathrm{KS}$ \\
\hline $\begin{array}{l}\text { Sebelum menggunakan metode Group } \\
\text { Investigation (GI) }\end{array}$ & - & $60 \%$ & $32,5 \%$ & $7,5 \%$ & - \\
\hline $\begin{array}{l}\text { Setelah menggunakan metode Group } \\
\text { Investigation (GI) pada siklus I }\end{array}$ & $5 \%$ & $70 \%$ & $22,5 \%$ & $2,5 \%$ & - \\
\hline $\begin{array}{l}\text { Setelah mengguknakan metode Group } \\
\text { Investigation (GI) pada siklus II }\end{array}$ & $17,5 \%$ & $67,5 \%$ & $15 \%$ & - & - \\
\hline
\end{tabular}

Tabel 2. Pengukuran Keaktifan Siswa Dalam Kegiatan Belajar Mengajar Aspek: kerjasama antarsiswa

\begin{tabular}{|l|c|c|c|c|c|}
\hline \multirow{2}{*}{ KEADAAN } & \multicolumn{5}{c|}{ PERSENTASE SKOR } \\
\cline { 2 - 6 } & $\mathrm{BS}$ & $\mathrm{B}$ & $\mathrm{C}$ & $\mathrm{K}$ & $\mathrm{KS}$ \\
\hline $\begin{array}{l}\text { Sebelum menggunakan metode Group } \\
\text { Investigation (GI) }\end{array}$ & - & $10 \%$ & $40 \%$ & $15 \%$ & - \\
\hline $\begin{array}{l}\text { Setelah menggunakan metode Group } \\
\text { Investigation (GI) pada siklus I }\end{array}$ & - & $22,5 \%$ & $70 \%$ & $7,5 \%$ & - \\
\hline $\begin{array}{l}\text { Setelah menggunakan metode Group } \\
\text { Investigation (GI) pada siklus II }\end{array}$ & $2,5 \%$ & $32,5 \%$ & $60 \%$ & $5 \%$ & - \\
\hline
\end{tabular}

Tabel 3. Pengukuran Keaktifan Siswa Dalam Kegiatan Belajar Mengajar Aspek: Mengeluarkan Pendapat Untuk Memecahkan Permasalahan

\begin{tabular}{|l|c|c|c|c|c|}
\hline \multirow{2}{*}{ KEADAAN } & \multicolumn{5}{c|}{ PERSENTASE SKOR } \\
\cline { 2 - 6 } & $\mathrm{BS}$ & $\mathrm{B}$ & $\mathrm{C}$ & $\mathrm{K}$ & $\mathrm{KS}$ \\
\hline $\begin{array}{l}\text { Sebelum menggunakan metode Group } \\
\text { Investigation (GI) }\end{array}$ & - & $17,5 \%$ & $45 \%$ & $37,5 \%$ & - \\
\hline $\begin{array}{l}\text { Setelah menggunakan metode Group } \\
\text { Investigation (GI) pada siklus I }\end{array}$ & - & $20 \%$ & $47,5 \%$ & $32,5 \%$ & - \\
\hline $\begin{array}{l}\text { Setelah menggunakan metode Group } \\
\text { Investigation (GI) pada siklus II }\end{array}$ & $7,5 \%$ & $22,5 \%$ & $57,5 \%$ & $12,5 \%$ & - \\
\hline
\end{tabular}

Tabel 4. Pengukuran Keaktifan Siswa Dalam Kegiatan Belajar Mengajar Aspek: Memberikan Pertanyaan (Bertanya).

\begin{tabular}{|l|c|c|c|c|c|}
\hline \multirow{2}{*}{ KEADAAN } & \multicolumn{5}{|c|}{ PERSENTASE SKOR } \\
\cline { 2 - 6 } & BS & B & C & K & KS \\
\hline
\end{tabular}




\begin{tabular}{|l|c|c|c|c|c|}
\hline $\begin{array}{l}\text { Sebelum menggunakan metode Group } \\
\text { Investigation (GI) }\end{array}$ & - & $17,5 \%$ & $47,5 \%$ & $35 \%$ & - \\
\hline $\begin{array}{l}\text { Setelah menggunakan metode Group } \\
\text { Investigation (GI) pada siklus I }\end{array}$ & $2,5 \%$ & $15 \%$ & $67,5 \%$ & $15 \%$ & - \\
\hline $\begin{array}{l}\text { Setelah menggunakan metode Group } \\
\text { Investigation (GI) pada siklus II }\end{array}$ & $7,5 \%$ & $22,5 \%$ & $57,5 \%$ & $12,5 \%$ & - \\
\hline
\end{tabular}

Dari keempat aspekyang ada pada keaktifan siswa dalam mengikuti KBM dapat terbukti adanya peningkatan persentase dari kolom indicator yang ada, yaitu BS (Biak Sekali), B (Baik), C (Cukup), K (Kurang) dan KS (Kurang Sekali). Jadi terbukti bahwa penerapan metode pembelajaran kooperatif Group Investigation (GI) pada proses pembelajaran mata pelajaran PMKR untuk siswa kelas XI TKRO 1 SMK Negeri 3 Kota Jambi dapat meningkatkan keaktifan siswa.

\section{KESIMPULAN}

Berdasarkan hasil penelitian dapat disimpulkan bahwa penerapan metode pembelajaran kooperatif Group Investigation (GI) dapat meningkatkan keaktifan siswa selama kegiatan belajar mengajar di kelas berlangsung. Pelaksanaan metode pembelajaran kooperatif Group Investigation (GI) siswa selalu dijadikan pusat pembelajaran, dalam metode ini siswa dituntut berperan aktif dalam setiap tindakan yang dilakukan mulai dari mengidentifikasikan topik sampai pada evaluasi. Peranan guru dalam pelaksanaan metode pembelajaran kooperatif Group Investigation (GI) dapat memberikan kemudahan bagi siswa untuk memahami suatu materi dalam mencapai kompetensi dasar tertentu oleh siswa, sehingga dapat meningkatkan kompetensi mata pelajaran PMKR siswa.

\section{DAFTAR PUSTAKA}

Arends, R.I. 1997. Classroom Instruction and Management. New Jersey: The Mc.Graw Hill Companies, Inc.

A. Suhaenah Suparno. 2001. Membangun Kompetensi Belajar. Jakarta: Direktorat Jenderal Pendidikan Tinggi Departemen Pendidikan Nasional.

Balitbang Depdiknas. 2002. Penilaian Berbasis Kelas. Jakarta: Depdikbud.

Enco Mulyasa. 2003. Kurikulum Berbasis Kompetensi: Konsep, Karakteristik, dan Implementasi. Bandung: Remadja Rosda Karya.

H.B. Sutopo. 2002. Metodologi Penelitian Kualitatif. Surakarta: Sebelas Maret University Press.

Kasihani Kasbolah. 2001. Penelitian Tindakan Kelas. Malang: Universitas Negeri Malang. Lie, Anita. 2004. Cooperative Learning: Mempraktikkan Cooperative Learning di Ruangruang Kelas. Jakarta: PT. Gramedia Widia Sarana Indonesia. 